\title{
Mitigating risks of tacit knowledge loss in state-owned enterprises in South Africa through knowledge management practices
}

\begin{tabular}{|c|c|}
\hline \multicolumn{2}{|c|}{$\begin{array}{l}\text { Authors: } \\
\text { Malefetjane Phaladi }{ }^{1} \\
\text { Patrick Ngulube }{ }^{2}\end{array}$} \\
\hline \multicolumn{2}{|c|}{$\begin{array}{l}\text { Affiliations: } \\
\text { 'Department of Library } \\
\text { Services, Durban University } \\
\text { of Technology, Durban, } \\
\text { South Africa }\end{array}$} \\
\hline \multicolumn{2}{|c|}{$\begin{array}{l}{ }^{2} \text { School of Interdisciplinary } \\
\text { Research and Graduate } \\
\text { Studies, College of Graduate } \\
\text { Studies, University of South } \\
\text { Africa, Pretoria, South Africa }\end{array}$} \\
\hline \multicolumn{2}{|c|}{$\begin{array}{l}\text { Corresponding author: } \\
\text { Malefetjane Phaladi, } \\
\text { MalefetjaneP@dut.ac.za }\end{array}$} \\
\hline \multicolumn{2}{|c|}{$\begin{array}{l}\text { Dates: } \\
\text { Received: } 13 \text { Sept. } 2021 \\
\text { Accepted: } 02 \text { Dec. } 2021 \\
\text { Published: } 01 \text { Feb. } 2022\end{array}$} \\
\hline \multicolumn{2}{|c|}{$\begin{array}{l}\text { How to cite this article: } \\
\text { Phaladi, M. \& Ngulube, P., } \\
2022, \text { 'Mitigating risks of } \\
\text { tacit knowledge loss in } \\
\text { state-owned enterprises } \\
\text { in South Africa through } \\
\text { knowledge management } \\
\text { practices', South African } \\
\text { Journal of Information } \\
\text { Management 24(1), a1462. } \\
\text { https://doi.org/10.4102/ } \\
\text { sajim.v24i1.1462 }\end{array}$} \\
\hline \multicolumn{2}{|c|}{$\begin{array}{l}\text { Copyright: } \\
\text { (c) 2022. The Authors. } \\
\text { Licensee: AOSIS. This } \\
\text { is licensed under the } \\
\text { Creative Commons } \\
\text { Attribution License. }\end{array}$} \\
\hline \multicolumn{2}{|l|}{ Read online: } \\
\hline 口ij: & $\begin{array}{l}\text { Scan this QR } \\
\text { code with your } \\
\text { smart phone or } \\
\text { mobile device } \\
\text { to read online. }\end{array}$ \\
\hline
\end{tabular}

Background: State-owned enterprises (SOEs) in South Africa face a serious challenge of knowledge loss caused largely by resignations, the ageing workforce and a lack of knowledge management $(\mathrm{KM})$ practices.

Objective: This article explores KM practices in the South African SOEs to mitigate the risks inherent in tacit knowledge loss.

Methods: The study adopted a mixed methods research strategy using an exploratory sequential design to identify KM practices and their effectiveness in addressing the issue of tacit knowledge loss. The qualitative data was collected through the interviews and document analysis of 2018 annual reports in nine SOEs across five market sectors. A survey questionnaire was distributed to 585 respondents, with a $25 \%$ response rate (145) for quantitative data in three SOEs.

Results: The results revealed that the majority of the SOEs lacked KM practices in their structures. The lack of KM practices implies that the SOEs are lagging behind in knowledge protective capacities to mitigate the risks inherent in the organisational tacit knowledge loss. With many South African SOEs, facing all these sorts of knowledge loss risks and a lack of KM practices to mitigate them, achieving the objectives of a developmental state remains a farfetched idea.

Conclusion: The absence of KM practices negatively affected knowledge transfer and retention in most of the SOEs. A lack of KM practices will negatively affect their performance and their sustainability to deliver on their developmental mandate. Investment in KM practices will assist SOEs to mitigate the risks associated with loss of organisational tacit knowledge.

Keywords: knowledge management practices; knowledge loss; South Africa; state-owned enterprises; knowledge transfer; knowledge retention.

\section{Introduction and background}

In the knowledge-based economy, organisational knowledge assets are the cornerstone and sources of superior performance, innovation and sustainability. The knowledge-based view (KBV) of the firm calls for the protection of organisational tacit knowledge assets through the investment in relevant knowledge management (KM) practices (Grant 1996; Phaladi 2021; Takeuchi 2013). Sultan Balbuena (2014:9) defines state-owned enterprises (SOEs) as entities established according to the statutory laws of the country; they can be either wholly or partially owned, with the government having a significant level of shareholding and ownership. Stateowned enterprises (SOEs) are the business entities owned by the government to meet the socioeconomic objectives or mandates of their home countries. They are economic transformation and job creation agents at the heart of economic and innovation development in many countries (Saxen \& Das 2021). In their own right, SOEs are knowledge-creating and knowledge-based organisations which play an important role in the knowledge economy (Benassi \& Landoni 2019). Globally, SOEs are economic drivers in both developed and non-developed countries (OECD 2018; Saxen \& Das 2021). In South Africa, SOEs are central to positioning the country as a developmental state and play a critical role in the job creation space (Gumede, Govender \& Motshidi 2011). State-owned enterprises play a significant role in the global knowledge economy (Benassi \& Landoni 2019). These enterprises are most prevalent in strategic sectors such as energy, minerals, infrastructure, and other utilities and, in some countries, development financial services. State-owned enterprises are also used as instruments for socioeconomic development in South Africa (Gumede et al. 2011), but many of them are in perpetual struggle facing the issue of 
organisational tacit knowledge loss, which is exacerbated by a lack of KM practices (Phaladi 2021). This emphasises the need for SOEs to manage their knowledge assets to effectively contribute to sustainable development. Knowledge-based theorists view SOEs as knowledge-creation enterprises, knowledge-sharing entities and knowledge-explorer agents (Benassi \& Landoni 2019; Landoni 2020; Nonaka \& Takeuchi 1995), which play a critical economic role in the global and national development agenda. However, SOEs are facing the risks of knowledge loss because of a lack of KM practices to mitigate these challenges (Kumar 2020).

The KBV on organisational tacit knowledge as a source of sustained competitive advantage places a greater emphasis on its proper management practices (Nisula \& Kianto 2016). Knowledge management practices comprise all strategies or practices aimed at ensuring knowledge production, application, retrieval, transfer, and retention that take place in the businesses (Zaim et al. 2018). Such practices would incorporate knowledge diagnostics, strategies, systems, policies, and processes to ensure successful management of organisational knowledge. Several studies have shown the value of KM practices in addressing the risks of knowledge loss in a number of sectors, namely, public sector (Cairo et al. 2015), manufacturing sector (Sumbal et al. 2020), energy sector (Sumbal et al. 2018), military sector (Singh \& Gupta 2020) and in the information technology project management environment (Rashid et al. 2020). Nevertheless, research on $\mathrm{KM}$ practices especially those aimed at addressing the phenomenon of knowledge loss in the SOEs remains limited. Landoni (2020) and Massaro, Dumay and Garlatti (2015) posit that only $3 \%$ of research on KM in the public sector had a focus on the SOEs. Globally, the majority of SOEs are experiencing a lack of $\mathrm{KM}$ practices dedicated to address knowledge loss risks (Kumar 2020; Sandelin, Hukka \& Katko 2019). In South Africa, there are limited studies focusing on $\mathrm{KM}$ in SOEs even though they are faced with the challenges of tacit knowledge loss risks (Phaladi 2021, 2011).

Existing literature on KM presents a consensus by researchers and practitioners that knowledge assets are sources of organisational performance such as profitability, competition and organisational effectiveness. It is for this reason, that a number of researchers caution organisations such as SOEs to be concerned about building and protecting their knowledge assets (Sandelin et al. 2019). Valmohammadi and Ahmadi (2015:132) argue that KM should no longer be treated as an option but rather a central obligation for companies anywhere across the globe, if they want to survive in the knowledgebased competition or economy. Knowledge management refers to the application of a set of management strategies or practices aimed at creating and protecting valuable organisational knowledge (Gürlek 2020:19). This definition resonates with KBV theory, which places a greater emphasis on knowledge as most important resource of organisations. Barney (2001) emphasises the need for organisations to invest in developing capabilities to ensure that knowledge assets remain non-substitutable by the competitors. Knowledge management practices ensure that those capabilities are in place.

\section{Problem statement}

Globally, SOEs are critical components of most economies, including many developed economies (OECD 2018). The SOEs are critical pillars for economic development and contribute to gross domestic products for many countries in the knowledge economy. The majority of them are experiencing knowledge transfer and retention challenges pertaining to knowledge loss caused by voluntary and involuntary turnover and a lack of retention practices (Sandelin et al. 2019; Susanty \& Salwa 2017). Commentators on the resource- and knowledge-based theory (Barney 2001; Buta 2015; Gürlek 2020; Takeuchi 2013) argue that organisations must invest in developing and retaining their firm-specific human and knowledge resources to avoid the dire consequences of knowledge loss. Nevertheless, a lack of organisational KM practices aimed at reducing knowledge loss remains a serious issue faced by many South African SOEs. State-owned companies need to invest in human resources and management practices that are valuable, rare, imitable and non-substitutable to maintain their performance and sustainability. Considering the fact that there are many public utilities in South Africa, the issues of knowledge loss risks and the lack of $\mathrm{KM}$ practices to mitigate them, could hamper the progress towards sustainable development goals of the country.

\section{Objectives of the study}

The purpose of this study was to explore the KM practices in the South African SOEs to mitigate the risks inherent in tacit knowledge loss. The study tried to tackle these issues from $\mathrm{KM}$ and human resource management perspectives and propose knowledge-driven practices to mitigate knowledge loss risks. The objectives were to:

- Identify KM practices currently in place in reducing the loss of organisational tacit knowledge.

- Assess the effectiveness of KM practices in addressing organisational tacit knowledge loss.

- Propose KM strategies to mitigate knowledge loss in SOEs.

\section{Literature review}

This study is rooted within knowledge-based theory of the firm and its related theories such as knowledge absorptive and protective capacities. Knowledge management practices are viewed as organisational processes that serve to build knowledge absorptive and protective capacities (Andersén 2012; Gürlek 2020; Phaladi 2021). The KBV of the firm calls for the protection of intangible assets of organisations such as knowledge, skills and abilities. The theory places an emphasis on the value of knowledge assets as sources of competitive advantage (Grant 1996). Many scholars and practitioners have invested more efforts into placing knowledge as sources of superior performance than explaining how firms should 
identify, develop, retain and integrate that knowledge into their business processes (Chaita \& Sibanda 2021; Donate \& De Pablo 2015). The current research into KM practices in the South African SOEs seeks to address that gap. According to Phaladi (2022), a lack of current research that focuses on KM practices for the reduction of organisational knowledge loss and building $\mathrm{KM}$ capacities remains a challenge for the knowledge practitioners in the SOE sector. Knowledge assets as a source of economic value for companies are ranked higher over other assets such as financial and physical assets in the knowledge economy (Grant 1996; Handa, Pagani \& Bedford 2019). Therefore, building capacity to manage and protect such assets has become imperative for knowledgebased organisations such as SOEs. However, many SOEs are experiencing knowledge loss risks largely because of a lack of KM practices and systems. It is for this reason that key KM theorists advance the arguments in favour of developing KM capacity through relevant practices (Kumar 2020; Nisula \& Kianto 2016; Zaim et al. 2018) that are largely aimed at offering strategies for enabling knowledge absorptive capacity (Cohen \& Levinthal 1990) and knowledge protective capacity (Andersén 2012).

Knowledge management presents a set of strategies, processes and systems for a company to develop and protect its knowledge resources especially knowledge of its human resources. Zaim et al. (2018) posit that KM practices should comprise of all strategies or systems aimed at ensuring that knowledge development, discovery, application, transfer and protection take place in the companies. Donate and De Pablo (2015:362) add that such practices should concentrate on ensuring the assimilation and application of existing knowledge to perform organisational activities, making decisions and problem solving easier and more effective for the company. The existing literature on $\mathrm{KM}$ and organisational performance indicates that $\mathrm{KM}$ practices have a positive and substantial influence on the performance of organisations (Valmohammadi \& Ahmadi 2015). Organisational knowledgedriven practices play a significant role in the development and facilitation of a knowledge-driven culture, behaviours, processes and innovation in organisations (Chaita \& Sibanda 2021; Dalkir 2020). In other words, KM practices help to guide and shape the desired knowledge-driven activities and behaviours. Sandelin et al. (2019:3-4) highlight a lack of functional structures, culture, management and leadership practices and KM infrastructures as some of the challenges faced by SOEs. Knowledge management practices could play a critical role in addressing all these issues. Most importantly, KM practices advance a knowledge-sharing, creation and retention culture. Therefore, companies investing in appropriate KM practices are likely to increase their knowledge absorptive and protective capacities (Andersén 2012; Mariano \& Walter 2015). Concisely, the prevalence of knowledge-driven practices enhances KM capacity in organisations.

In the modern global knowledge economy, KM has become a critical success factor for knowledge-driven companies. As a result, an investment in appropriate KM capacity is not an exception for SOEs as knowledge-driven companies. Knowledge management practices are essential to develop KM capacity (Kumar 2020); KM capacity denotes an investment in business processes aimed at generating and sharing knowledge continuously within firms (Gope, Elia \& Passiante 2018; Hsiao, Chen \& Chang 2011). Such an investment will inevitably present these companies with opportunities to reshape current knowledge resources and create new ones by acquiring it from the staff, as well as external shareholders and marketplace (Hsiao et al. 2011). Gope et al. (2018:650) assert that KM practices provide an important foundation and organisational infrastructure to boost KM capacity within firms. Such practices should include procedures and strategies that are aimed at developing, using and protecting firm-specific knowledge resources. Firms invest in the acquisition of knowledge resources to obtain competitive advantage and superior performance over their competitors. However, unless they invest in knowledge-driven practices for the management and protection of these knowledge resources they will never be able to sustain their performance.

\section{Methodology}

Knowledge production in a scientific project is largely dependent on research strategies employed in the process. This study adopted a mixed methods research (MMR) approach, by means of an exploratory sequential design. The justification for the use of the MMR was for the researchers to produce a complete and complementary picture, from different perspectives and lenses, pertaining to the complex problems of organisational KM practices in selected South African SOEs. Mixed methods research is best suited for studying complex research issues from different perspectives because of its strengths to offer complementarity, comprehensiveness, multiplicity in the data collection and analysis processes (Ngulube 2020; Creswell \& Creswell 2018; Creswell \& Plano Clark 2018). Ngulube (2019) also advocates the use of MMR in KM studies in order for KM researchers to take a methodological turn and embrace a diversity of methodologies including MMR. The study followed two distinct research methodologies. Qualitative research methodology was used in the first phase and quantitative research methodology was employed in the second phase. Qualitative data was collected from nine state-owned entities across five industry sectors, using an analysis of their purposively selected annual reports and interviews with human resource managers. The process of data collection included the following: (1) interviews with 20 human resource managers, (2) document analysis of their 2018 annual reports, and (3) a survey questionnaire in the quantitative phase that was distributed to the employees and KM practitioners in the SOEs sector. The results of the interviews and document analysis in the qualitative phase were used to develop the survey questionnaire for testing in the quantitative phase. The survey questionnaire was distributed to a larger population of employees and KM practitioners in the second quantitative phase. In this phase, the questionnaire was distributed to 585 randomly selected respondents in three SOEs and KM 
practitioners in the sector that agreed to participate in the quantitative phase of the study. The sample size represented $10 \%$ of the population. A response rate of 145 was obtained for the survey component.

\section{Presentation of research findings}

Considering the fact that this study is an exploratory sequential MMR design, the exposition of the results is made in two parts, starting with the qualitative research results from the interviews and analysis of the annual reports, followed by the quantitative research results.

\section{Qualitative research findings}

In order to address the research objective on KM practices currently in place regarding the phenomenon of organisational tacit knowledge loss, this section pursues answers to the following research question: What KM initiatives are currently in place to manage tacit knowledge loss in the SOEs? The interviews conducted with 20 purposively selected human resource (HR) managers discovered that the majority of SOEs $(67 \%)$ were lacking in key KM practices such as coaching and mentoring, knowledge harvesting, programmes for retiring subject matter experts, job rotation, succession planning and job shadowing. The lack of KM practices was a serious challenge in many SOEs largely because of the fact that KM was not formally adopted in their structures, functions, processes and systems. However, the findings of the qualitative interviews also revealed that the minority of the HR managers identified these knowledge-driven practices as some of the strategies used to manage tacit knowledge loss in their organisations. Besides, some of these practices mentioned were still very much in the conceptual stages in $33 \%$ of the SOEs that had a formalised KM structure and systems. For instance, one HR manager from a developmental finance state-owned entity (SOE1) where KM was formalised, expressed the position about coaching as part of the programme for the retiring knowledge experts as follows:

'It has not taken off, we have just started. So, basically we have started with the coaching, we have identified an expert who does coaching for people who are going on retirement. The next leg of it is the knowledge management part, which is where we have now partnered with the knowledge management to say let's begin to help them to impart knowledge. However, it is still at an infancy stage. It has not really taken off this one.' (Interviewee \#2, Gender: Female, 2019)

It is interesting to note that some of KM practices mentioned by HR managers such as master classes, job rotation, expert forums, on-the-job shadowing, coaching and mentoring, communities of practice, knowledge harvesting, programmes for retiring subject matter experts and succession planning had not really put into practice in many of the SOEs. This is irrespective of whether they had a formalised KM function and structure or not. Seventeen human resource managers identified succession planning as part of a KM strategy that was in place and guided by HRM. However, some of these managers also posited that it is still in its infancy, because the succession planning had not yet been formalised. In some cases, they developed policies on succession planning, but the implementation remained a serious problem. One HR manager of SOE3 expressed it this way:

'I think ... no, we are still lacking behind on that. We are, I mean, I think we still have a policy that is yet to be approved on succession management. We have not made any strides there.' (Interviewee \#5, Gender: Male, 2019)

The results of the reviewed annual reports identified the following $\mathrm{KM}$ practices in place, regardless of whether the companies pursued KM or not:

- Succession management plans.

- Collaboration platforms or knowledge exchange platforms.

- Staff and stakeholders engagement forums.

- Secondments of staff.

- Training and development investment strategies.

- Attendance and presentation of papers at conferences (local and international).

- Workplace meetings.

- In-house bursary programmes.

- On-the-job boarding.

- In-house academies.

- Coaching and mentoring programmes.

- Graduate internship programmes.

- Information resource centres.

- Records management.

- Knowledge capture systems.

- Interviews with industry experts.

These KM practices were found in more than one of the reviewed annual reports. Of particular interest to the researchers was the fact that some of the KM activities such as knowledge harvesting, master classes, expert forums, on-the-job shadowing and job rotations that were mentioned during the interviews with the participants were not reflected in their annual reports that were reviewed. Similarly, some of the KM practices identified in the annual reports reviewed were not mentioned by the participants in the interviews. This finding indicates that many SOEs in the study did not formalise KM practices. This is the reason for the lack of reporting on such practices.

\section{Quantitative research results}

This section presents a numerical analysis of the 145 respondents from the quantitative phase. The majority of responses were from male $82(57 \%)$ and female $63(43 \%)$. The research answers were randomly obtained by a survey questionnaire in three SOEs. The responses were from $20 \mathrm{KM}$ practitioners, 13 librarians, nine information technology managers and 103 were from other employees.

\section{Knowledge management practices and their effectiveness}

The responses on the effectiveness of organisational KM practices or strategies varied from one variable to another. Figure 1 presents a diagrammatic representation of the quantitative answers. The responses showed that $43 \%$ of the survey participants mentioned that coaching as a KM 


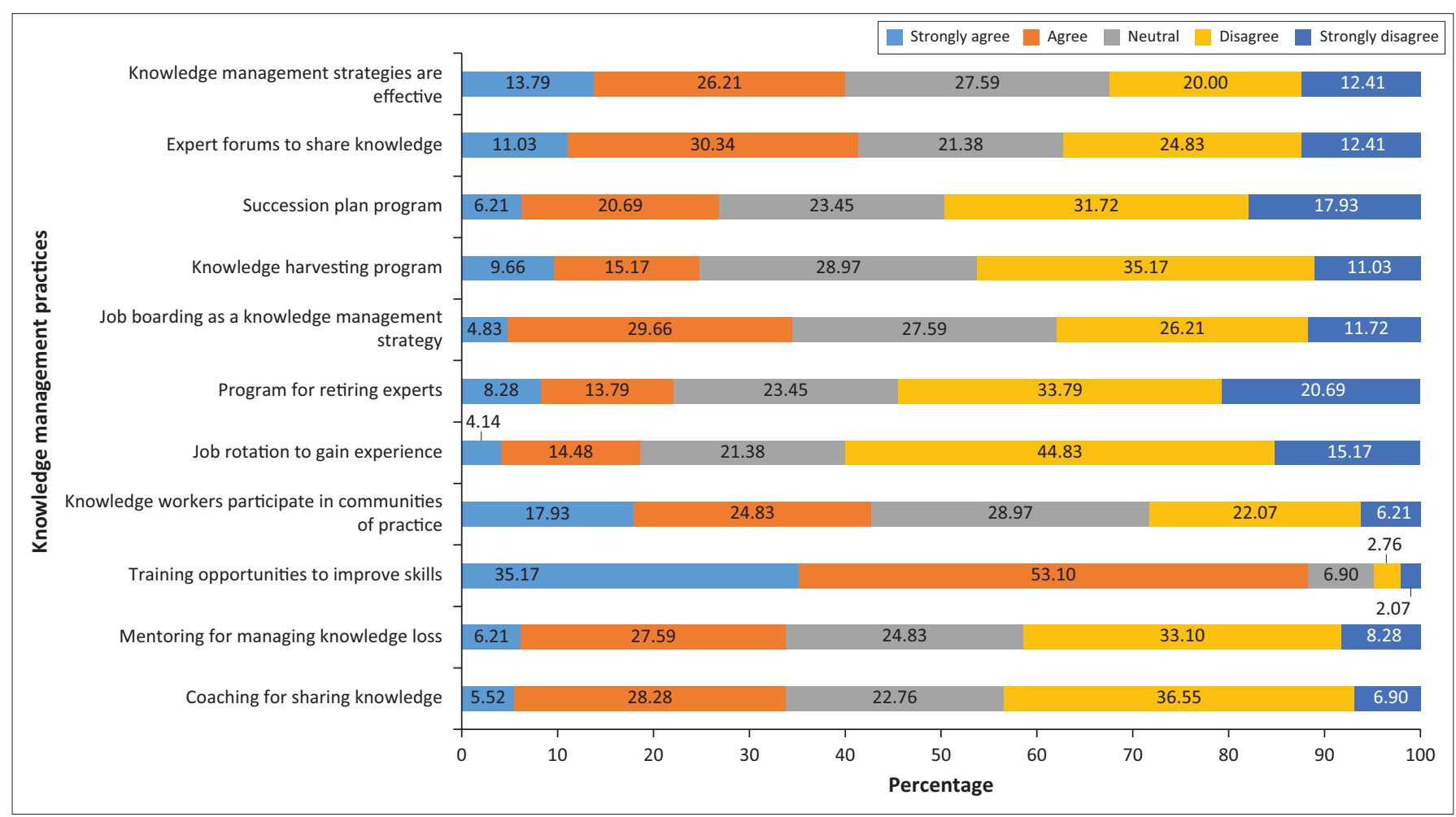

Source: Phaladi, M.P., 2021, 'Framework for integrating knowledge management and human resource management for the reduction of organisational knowledge loss in selected South African state-owned enterprises', PhD thesis, University of South Africa

FIGURE 1: Knowledge management practices and their effectiveness.

strategy did not apply, indicating that the state-owned companies did not apply coaching as a KM practice. In contrast, a minority share of respondents (34\%) indicated that their public entities make use of coaching as a knowledge-driven practice, while $23 \%$ of the respondents did not know whether coaching as a KM practice existed in their company. In summary, coaching was not used as a part of KM strategy to transfer knowledge in the majority of the SOEs. Similarly, the respondents' answers on mentoring as a way of preventing knowledge loss painted almost a similar picture. A major number of respondents (41\%) indicated that mentoring did not apply to their entities. A smaller share of respondents (34\%) posited that mentoring was not applicable to their utilities. A further $25 \%$ of respondents did not know whether mentoring is used as a KM practice.

On a positive note, SOEs offered training and development opportunities for their human resources to improve their knowledge and skills, as $88 \%$ respondents agreed that their companies presented them with opportunities to enhance their knowledge and skills. Communities of practices (CoPs) were applied as knowledge-driven practices in the majority of the SOEs. This was evidently clear with a majority share of the respondents (43\%) indicating that their companies encouraged their knowledge workers to vigorously partake in such CoPs, while a minority share (28\%) claimed that CoPs did not apply. On a shocking note, a noticeable number of respondents $(29 \%)$ did not know whether CoPs are actively encouraged in their state-owned companies.
According to the researcher of the current research, job rotation as a KM practice remains a challenge in many of the state-owned companies as a larger number of respondents $(60 \%)$ contended that the public entities did not use the practice for knowledge workers to grow experience by moving them across different business units or divisions. A small but noticeable share of respondents (21\%) did not give information on the variable indicating that they are less informed about job rotation in their organisations, while 19\% replied that the question did not apply in their case.

The majority of SOEs lacked a programme focused on retiring experts to share and retain their knowledge and skills. A large number of respondents (55\%) concurred that their SOEs do not have such a programme, while $22 \%$ indicated that there was a programme in place for their ageing workforce. A noticeable minority (38\%) of respondents either disagreed or strongly disagreed that job shadowing was a KM practice in place, while $34 \%$ indicated that it was part of the KM strategy in their organisations. Again, like in other variables discussed in this section, a small number of respondents (28\%) were less informed whether job shadowing was employed as a KM practice.

The majority of the SOEs did not have a knowledgeharvesting programme as KM practice. The data revealed that the majority of respondents $(46 \%)$ contended that a knowledge-harvesting programme did not apply in their public utilities, while $25 \%$ of respondents responded, conversely, that their employers have a knowledge harvesting practice. A noticeable minority share of respondents $(29 \%)$ indicated 'neutral' to the statement, indicating that they 
were less informed on whether a knowledge-harvesting programme did apply in their companies as part of KM.

In terms of succession planning, the majority of the SOEs were lacking behind. A majority share of respondents (50\%) pointed to a lack of it in their responses, while a minority of the respondents $(27 \%)$ claimed that a succession plan was used as a KM practice, and a smaller share $(23 \%)$ of respondents did not know of the succession planning practice in their SOEs.

Expert forums were proving to be a very popular KM strategy in many of the SOEs. Knowledge workers saw this as a good strategy to share their knowledge and used it. The majority of respondents (41.4\%) confirmed that expert forums applied in their state-owned entities, whereas $37.2 \%$ indicated that their companies did not provide expert forums as a knowledge transfer strategy. A smaller share (21.4\%) of respondents did not know of the existence of expert forums as knowledge sharing and transfer platforms.

Concerning the research question on the overall effectiveness of KM strategies or practices in ensuring that state-owned entities reduce knowledge loss, the majority of the respondents $(40 \%)$ revealed that these knowledge-driven practices are useful, whereas a minority share (32\%) of respondents claimed that these practices were ineffective. A noticeable small share $(28 \%)$ of respondents did not have any opinion on whether the practices were effective.

\section{Discussion of the research findings}

Knowledge management practices are inadequate in the majority of the South African SOEs. This lack of KM practices implies that SOEs are way behind in KM capacities. Both the qualitative and quantitative findings revealed job rotation, knowledge harvesting, succession planning, and programmes for the retiring subject matter experts, coaching and mentoring as key KM practices that were lacking in the SOEs. What complicates the conditions of KM in these state-owned entities is the fact many of them are experiencing knowledge sharing and protection issues relating to knowledge loss caused by voluntary and involuntary turnover and a lack of KM practices. The study revealed that KM practices could serve as important considerations to regulate or manage knowledge loss in the SOEs. The existence of KM practices apparently has a substantial influence on the performance of the business (Kianto et al. 2019). Therefore, a lack of knowledge-driven practices will have a negative effect on the performance of SOEs and threaten their sustainability. Concisely, the constant non-existence of investment focus in $\mathrm{KM}$ practices will put the economic transformational mandate of SOEs at the peripheral side of their activities and will therefore lead to operational inefficiencies and inferior business performance outcomes. Dzenopoljac et al. (2018:77) postulate that knowledge is a key strategic resource which enables business enterprises to develop optimum integration of tangible and intangible assets that will create excellent and more business performance outcomes.

In the qualitative component of the study, some HR managers acknowledged job shadowing and rotations as practices available to support KM processes in their respective SOEs. However, the findings of the quantitative phase presented a different picture in that job shadowing and rotations as KM strategies were found not to be applicable in the majority of SOEs. A large share of respondents $(60 \%)$ indicated that job rotation practice was not an applicable strategy available to their personnel to increase knowledge and experience through rotating them across distinct business units or departments. For knowledge to be of value to the business, it must be able to flow across various process units and be embedded into organisational routines (Chuang, Jackson \& Jiang 2016). Job rotation as a KM practice should be available to all employees across functional units and be entrenched in the business processes. The lack of KM practices such as job rotation and job shadowing would mean that the sharing of business knowledge remained in silos. Such a lack of KM practices prevents much of the organisational knowledge from flowing systematically and being embedded across various business units or areas. This would mean that knowledge absorptive capacity opportunities are limited to silos.

A challenge that many organisations often encounter is the absence of succession plans in as far as the sharing of knowledge of the older cohorts of workers is concerned. As a result, the younger generation of knowledge workers are denied opportunities to absorb the knowledge and skills of the older generation of workers (Cohen \&Levinthal 1990). Consequently, knowledge absorptive capacity for the younger generation of knowledge workers remains a challenge. This has been the case in the majority of the SOEs as they lacked strategies on succession planning. The older generation of workers are knowledgeable firm-specific human resources, who have built up the much-needed knowledge assets over the years and possess valuable and strategic organisational knowledge for ensuring a sustainable competitive advantage (Grant 1996). Their exit could therefore lead to a disappearance of missioncritical competencies in many SOEs, unless there is a focused investment in building absorptive, and retentive or protective capacities for such knowledge and skills (Andersén 2012). Such competencies are the key to the success of their entities and will therefore hinder their performance and impact negatively on their sustainability in the longer term (Durst \& Zieba 2020; Kumar 2020). The non-existence of succession planning practices create a serious problem or vacuum for retiring workers to transfer their subject matter expertise and knowledge. This is problematic especially if their replacements are not well identified in advance. The prevailing circumstances in the SOEs mean that employees are denied opportunities to be coached and mentored into the critical-mission roles in advance before the older experts retire.

The majority of the SOEs lacked coaching and mentoring programmes. Coaching and mentoring did not apply or were not regarded as KM practices. A large number of respondents posited that coaching and mentoring were not used as knowledge-sharing strategies to reduce knowledge loss. Belle (2020) agrees that non-existence of coaching and mentoring opportunities would inevitably deny organisational members to learn from their seniors, mentors or subject matter experts. 
Similarly, a lack of such opportunities also impacts adversely on the older subject matter experts who may be willing to share their expertise and knowledge with the younger cohorts of knowledge workers. Trees (2016) and Appelbaum et al. (2012) indicate that the older cohorts of workers or rather the baby boomers, have the inclination to impart what they know with the younger group of knowledge workers. However, the organisational conditions do not allow or rather nurture such kind of knowledge behaviours to flourish. In a nutshell, a lack of succession planning strategies, in particular through interventions such as coaching and mentoring practices to share their knowledge and skills frustrate the willingness of the older generation of workers to transfer their experience in their subject domains.

Pertaining to the research objective on the overall effectiveness of knowledge-driven practices, the majority of respondents $(40 \%)$ revealed that those few practices that were already in place were effective to a certain degree. However, a noticeable minority of respondents $(30 \%)$ provided a contrasting view on the effectiveness of the KM practices, which posited that the practices were not that effective. To a certain degree, it can be deduced that the effectiveness of KM practices in the SOEs remained a problem area. This is largely because, in addition to the $32 \%$ of the respondents who rated the practices as not effective, another minority share of respondents (28\%) indicated that they were less informed on the effectiveness of the KM practices. If indeed, they were aware of the existence of such practices they would have indicated likewise in affirmation. Furthermore, it can be argued that the question on the effectiveness of knowledge practices was not that significant for those SOEs that did not have such practices in place. The qualitative data revealed that only $33 \%$ of the SOEs had formalised KM practices whereas the rest of the majority $(67 \%)$ did not. The data is largely based on a few such as expert forums and communities of practice, which have been prevalent in one SOE or the other.

\section{Limitations and suggestions for further research}

This research project has several limitations pertaining to KM practices in SOEs. This research project was carried out in a limited number of South African SOEs across five market sectors while nine SOEs took part in the qualitative phase and three in the quantitative phase of the study. Furthermore, it was limited to SOEs listed in Schedule 2, 3A and 3B of the Public Finance Management Act (National Treasury 2015). As a result, the findings should be used with a caution by the state-owned entities at provincial and local levels and those from other sectors that were not part of the study. For this reason, any future research on KM practices should focus on Schedule 1 SOEs and those operating at provincial level. The research project is based on South African local context. Therefore, the findings of this study should not be generalised to other contexts in other nations and their specific SOEs sectoral contexts. The survey used in the quantitative phase was limited to only three SOEs. As such the research findings should be interpreted with caution. A survey involving more SOEs with larger sample sizes is therefore recommended for future studies.

\section{Conclusion and recommendations}

A good balance of KM practices will have a substantial influence on the organisational performance (Gope et al. 2018; Nisula \& Kianto 2016). Therefore, there is a need for SOEs to invest in KM practices in order to maintain their competitive advantage, otherwise their mandate and role in a developmental state remains a far-fetched idea. In so far as knowledge absorptive capacity and protective capacity issues are concerned, the study concludes that the investment in knowledge-driven practices aimed at addressing organisational tacit knowledge loss and its transfer will go a long way in strengthening KM capacity in SOEs. In order to address the challenges regarding knowledge loss and human resource turnover, KM practices could act as significant control variables for effective management and reduction of organisational knowledge loss. This study makes the following recommendations for SOEs. Firstly, there is a need to formulate strategies for intergenerational knowledge sharing. Secondly, SOEs need to have succession planning practices in place to ensure that intergenerational learning, knowledge creation and transfer take place. Thirdly, there is a need to implement job rotations for ensuring that organisational members gain experience and knowledge across business units. This will ensure that organisational knowledge is embedded across business processes. Fourthly, coaching and mentoring programmes should be developed to ensure effective management and sharing of organisational knowledge between the older generation of knowledge workers and the younger ones. Lastly, SOEs will need to implement KM structures, systems, roles and resources to drive the effective implementation and investment in the required KM practices.

\section{Acknowledgements}

The authors would like to like to acknowledge the stateowned enterprises in South Africa that took part in this project. Additionally, they would like to extend their gratitude to the human resource managers, employees and KM practitioners in the public utility space that participated both in the qualitative and quantitative phase of the study.

\section{Competing interests}

The authors have declared that no competing interest exists.

\section{Authors' contributions}

M.P. conceptualised and collected the data; P.N. supervised the study and assisted in its conceptualisation. Their contribution to this article was $60 \%$ and $40 \%$, respectively.

\section{Ethical considerations}

This research was approved by the Department of Information Science Ethics Review Committee, University of South Africa \# 2020 DIS-0018. 


\section{Funding information}

This article is part of a doctoral thesis. The corresponding author received grant from Tshwane University of Technology, Research and Innovation portfolio for the transcription of the qualitative data in the first phase of the study. Furthermore, University of South Africa granted the bursary for the statistical analysis in the quantitative phase and language editing services.

\section{Data availability}

The data used in this study are available and can be shared when required or necessary upon reasonable request from the corresponding author M.P.

\section{Disclaimer}

The views and opinions expressed in this article are those of the authors and do not necessarily reflect the official policy or position of any affiliated agency of the authors.

\section{References}

Andersén, J., 2012, 'Protective capacity and absorptive capacity: Managing the balance between retention and creation of knowledge-based resources',
The Learning Organization 19(5), 440-452. https://doi.org/10.1108/096964712 11239730

Appelbaum, S.H., Gunkel, H., Benyo, C., Ramadan, S., Sakkal, F. \& Wolff, D., 2012, 'Transferring corporate knowledge via succession planning: Analysis and Solutions - Part 1', Industrial \& Commercial Training 44(5), 281-289. https://doi. org/10.1108/00197851211245031

Barney, J., 2001, 'Is the resource-based view a useful perspective for strategic management research? Yes', Academy of Management Review 26(1), 41-56. https://doi.org/10.5465/amr.2001.4011938

Belle, S.M., 2020, 'Reflections: Mentoring in knowledge management for development', Knowledge Management for Development Journal 15(1), 109-115.

Benassi, M. \& Landoni, M., 2019, 'State-owned enterprises as knowledge-explorer agents', Industry and Innovation 26(2), 218-241. https://doi.org/10.1080/136627 16.2018.1529554

Buta, S., 2015, 'Human capital theory and human resource management: Implications in development of knowledge management strategies', ECOFORUM 4(1), 155-162.

Cairo, O., Salcedo, J.S. \& Gutierrez-Garcia, J.O., 2015, 'Crowdsourcing information for knowledge-based design of routes for unscheduled public transport trips', Journal of Knowledge Management 19(3), 626-640. https://doi.org/10.1108/JKM-02of Knowledge

Chaita, M.V. \& Sibanda, W., 2021, 'The role of knowledge in enhancing SMME innovation: The case of Knowsley - Northwest Region of England', International Journal of Knowledge Management 17(1), 93-112. https://doi.org/10.4018/ IJKM.2021010106

Chuang, C., Jackson, S.E. \& Jiang, Y., 2016, 'Can knowledge-intensive teamwork be managed? Examining the roles of HRM systems, leadership, and tacit knowledge', Journal of Management 42(2), 524-554. https://doi.org/10.1177/0149206313478189

Cohen, W.M. \& Levinthal, D.A., 1990, 'Absorptive capacity: A new perspective on learning and innovation', Administrative Science Quarterly 35(1), 128-152. https://doi.org/10.2307/2393553

Creswell, J.W. \& Creswell, J.D., 2018, Research design: Qualitative, quantitative \& mixed methods approaches, 5th edn., Sage, Los Angeles, CA.

Creswell, J.W. \& Plano Clark, V.L., 2018, Designing and conducting mixed methods research, 3rd edn., Sage, Los Angeles, CA.

Dalkir, K., 2020, 'The role of human resources (HR) in tacit knowledge sharing', in Information Resources Management Association, Information Diffusion Management and Knowledge Sharing: Breakthroughs in Research and Practice, pp. 490-512, IGI Global, United States. https://doi.org/10.4018/978-1 7998-0417-8.ch024

Donate, M.J. \& De Pablo, J.D.S., 2015, 'The role of knowledge-oriented leadership in knowledge management practices and innovation', Journal of Business Research 68, 360-370. https://doi.org/10.1016/j.jbusres.2014.06.022

Durst, S. \& Zieba, M., 2020, 'Knowledge risks inherent in business sustainability', Journal of Cleaner Production 251, 1-10. https://doi.org/10.1016/j.jclepro. 2019.119670

Dzenopoljac, V., Alasadi, R., Zaim, H. \& Bontis, N., 2018, 'Impact of knowledge management processes on business performance: Evidence from Kuwait', Knowledge Process Management 25, 77-87. https://doi.org/10.1002/kpm.1562
Gope, S., Elia, G. \& Passiante, G., 2018, 'The effect of HM practices on knowledge management capacity: A comparative study in Indian IT industry', Journal of Knowledge Management 22(3), 649-677. https://doi.org/10.1108/JKM-10Knowledge

Grant, R.M., 1996, 'Towards a knowledge-based theory of the firm', Strategic Management Journal 17(Winter special issue), 109-122. https://doi.org/10.1002/ smj.4250171110

Gumede, W., Govender, M. \& Motshidi, K., 2011, 'The role of South Africa's stateowned development finance institutions (DFIs) in building a democratic developmental state', Policy Brief 3, 1-8.

Gürlek, M., 2020, Tech development through hrm, Emerald Publishing Limited, Bingley.

Handa, P., Pagani, J. \& Bedford, D., 2019, Knowledge assets and knowledge audits Working methods for knowledge management, Emerald Publishing Limited, Bingley.

Hsiao, Y., Chen, C. \& Chang, S., 2011, 'Knowledge management capacity andorganizational performance: The social interaction view' International Journal of Manpower 32(5/6), 645-660. https://doi.org/ 10.1108/01437721111158242

Kianto, A., Shujahat, M., Hussain, S., Nawaz, F. \& Ali, M., 2019, 'The impact of knowledge management on knowledge worker productivity', Baltic Journal of Management 14(1), 178-197. https://doi.org/10.1108/BJM-12-2017-0404

Kumar, S., 2020, 'Knowledge risk management for the state-owned enterprises-Indian scenario', in S. Durst \& T. Henschel (eds.), Knowledge risk management, pp. 89-106, Springer, Berlin.

Landoni, M., 2020, 'Knowledge creation in state-owned enterprises', Structural Change and Economic Dynamics 53, 77-85. https://doi.org/10.1016/j. strueco.2020.01.001

Mariano, S. \& Walter, C., 2015, 'The construct of absorptive capacity in knowledge management and intellectual capital research: content and text analyses', Journal of Knowledge Management 19(2), 372-400. https://doi.org/10.1108/JKM-082014-0342

Massaro, M., Dumay, J. \& Garlatti, A., 2015, 'Public sector knowledge management: A structured literature review', Journal of Knowledge Management 19(3), 530-558. https://doi.org/10.1108/JKM-11-2014-0466

National Treasury, 2015, Public institutions listed in PFMA schedule 1, 2, 3A, 3B, 3C and 3D, Republic of South Africa, National Treasury, Pretoria.

Ngulube, P., 2019, 'Mapping methodological issues in knowledge management research, 2009-2014', International Journal of Knowledge Management 15(1) 85-100. https://doi.org/10.4018/IJKM.2019010106

Ngulube, P., 2020, 'Mixed methods research in knowledge management studies (2009-2014): A content analysis of journal articles', Journal of Information \& Knowledge Management 19(3), 1-23. https://doi.org/10.1142/S0219649220500161

Nisula, A. \& Kianto, A., 2016, 'The role of knowledge management practices in supporting employee capacity for improvisation', The International Journal of Human Resource Management 27(17), 1920-1937. https://doi.org/10.1080/0958 5192.2015.1088885

Nonaka, I. \& Takeuchi, H., 1995, The knowledge-creating company, Oxford University Press, New York, NY.

OECD, 2018, Ownership and governance of state-owned enterprises: A compendium of national practices, viewed 30 April 2021, from https://www.oecd.org/corporate/ ownership-and-governance-of-state-owned-enterprises-a-compendium-ofownership-and-gover
national-practices.htm.

Phaladi, M.P., 2011, 'Knowledge transfer and retention: the case of a public water utility in South Africa', Masters thesis, University of Stellenbosch.

Phaladi, M.P., 2021, 'Framework for integrating knowledge management and human resource management for the reduction of organisational knowledge loss in selected South African state-owned enterprises', PhD thesis, University of South Africa.

Phaladi, M.P., 2022, 'Studying knowledge management and human resource management practices in the state-owned entities using mixed methods research design', in P. Ngulube (ed.), Handbook of research on mixed methods research in information science, pp. 340-361, IGI Global, Hershey, PA. https://doi.org/ 10.4018/978-1-7998-8844-4.ch017

Rashid, M., Clarke, P.M. \& O'Connor, R.V., 2020, 'A mechanism to explore proactive knowledge retention in open source software communities', Journal of Software: Evolution and Process 32, 1-10. https://doi.org/10.1002/smr.2198

Sandelin, S.K., Hukka, J.J. \& Katko, T.S., 2019, 'Importance of knowledge management at water utilities', Public Works Management \& Policy 1-17. https://doi. org/10.1177/1087724X19870813

Saxen, N.K. \& Das, N., 2021, 'Competitive pressure and the moderating role of the knowledge network on internationalization intent of Indian state-owned enterprises', IIM Kozhikode Society \& Management Review preprint, 1-15. https://doi.org/10.1177/22779752211015529

Singh, M.K. \& Gupta, V., 2020, 'Critical types of knowledge loss in military organisations', VINE Journal of Information and Knowledge Management Systems (pre-print), 1-18. https://doi.org/10.1108/VJIKMS-09-2019-0152

Sultan Balbuena, S., 2014, 'State-owned enterprises in Southern Africa: a stocktaking of reforms and challenges'. OECD Corporate Governance Working Paper 13, 1-52.

Sumbal, M.S., Tsui, E., Cheong, R. \& See-To, E.W.K., 2018, 'Critical areas of knowledge loss when employees leave in the oil and gas industry', Journal of Knowledge Management 21(1), 180-196. https://doi.org/10.1108/JKM-082017-0373 
Sumbal, M.S., Tsui, E., Durst, S., Shujahat, M., Irfan, I. \& Ali, S.M., 2020, 'A framework to retain the knowledge of departing knowledge workers in the manufacturing industry', VINE Journal of Information and Knowledge Management Systems 50(4), 631-651. https://doi.org/10.1108/VJIKMS-062019-0086

Susanty, A.I. \& Salwa, M., 2017, 'Knowledge management practices and organizational learning have positive impacts on organizational performance of state-owned enterprises in Indonesia', Mediterranean Journal of Social Sciences 8(3), 281-292. https://doi.org/10.5901/mjss.2017.v8n3p281

Takeuchi, H., 2013, 'Knowledge-based view of strategy', Universia Business Review (Cuarto Trimestre), 68-79.
Trees, L., 2016, Knowledge transfer mentoring - Part 1 why your km strategy should include mentoring, viewed 16 August 2021, from https://www.kmworld.com/ Articles/Editorial/Features/Knowledge-transfer-mentoring-Part-1-Why-your-KMArticles/Editorial/Features/Knowledge-transfer-m
strategy-should-include-mentoring--113130.aspx.

Valmohammadi, C. \& Ahmad, M., 2015, 'The impact of knowledge management practices on organisational performance: A balanced scorecard approach', Journal of Enterprise Information Management 28(1), 131-159. https://doi.org/10.1108/JEIM-09-2013-0066

Zaim, H., Keceli, Y., Jaradat, A. \& Kastrati, S., 2018, 'The effects of knowledge management processes on human resource management: moderating role of management processes on human resource management: moderating role of 9(3), 310-328. https://doi.org/10.1108/JSTPM-02-2018-0011 